\title{
Colorful niches of phototrophic microorganisms shaped by vibrations of the water molecule
}

\author{
Maayke Stomp ${ }^{1,3}$, Jef Huisman ${ }^{1,2,3}$, Lucas J Stal ${ }^{1,2}$ and Hans CP Matthijs ${ }^{1}$ \\ ${ }^{1}$ Aquatic Microbiology, Institute for Biodiversity and Ecosystem Dynamics, University of Amsterdam, \\ Amsterdam, The Netherlands and ${ }^{2}$ Marine Microbiology, Netherlands Institute of Ecology (NIOO-KNAW), \\ Centre for Estuarine and Marine Ecology, Yerseke, The Netherlands
}

\begin{abstract}
The photosynthetic pigments of phototrophic microorganisms cover different regions of the solar light spectrum. Utilization of the light spectrum can be interpreted in terms of classical niche theory, as the light spectrum offers opportunities for niche differentiation and allows coexistence of species absorbing different colors of light. However, which spectral niches are available for phototrophic microorganisms? Here, we show that the answer is hidden in the vibrations of the water molecule. Water molecules absorb light at specific wavebands that match the energy required for their stretching and bending vibrations. Although light absorption at these specific wavelengths appears only as subtle shoulders in the absorption spectrum of pure water, these subtle shoulders create large gaps in the underwater light spectrum due to the exponential nature of light attenuation. Model calculations show that the wavebands between these gaps define a series of distinct niches in the underwater light spectrum. Strikingly, these distinct spectral niches match the light absorption spectra of the major photosynthetic pigments on our planet. This suggests that vibrations of the water molecule have played a major role in the ecology and evolution of phototrophic microorganisms.
\end{abstract}

The ISME Journal (2007) 1, 271-282; doi:10.1038/ismej.2007.59; published online 12 July 2007

Subject Category: microbial population and community ecology

Keywords: microbial evolution; molecular vibrations; niche differentiation; photosynthesis; phytoplankton competition; spectral irradiance

\section{Introduction}

In the late 19th century, Professor Theodor W Engelmann was the first to demonstrate that phototrophic organisms utilize specific parts of the light spectrum. He produced a 'living action spectrum', by illuminating filaments of the green alga Spirogyra with a light spectrum created by a prism glass. This revealed that oxygen-dependent bacteria accumulated near those parts of the algal filaments illuminated with red and blue light, thus demonstrating that the pigment chlorophyll absorbs red and blue light for photosynthesis (Engelmann, 1882). One year later, in 1883, Engelmann discovered the utilization of infrared wavelengths by purple bacteria (Engelmann, 1883). Since then, many photosynthetic pigments have been identified, each with its own

Correspondence: Professor J Huisman, Aquatic Microbiology, Institute for Biodiversity and Ecosystem Dynamics, University of Amsterdam, Nieuwe Achtergracht 127, 1018 WS Amsterdam, The Netherlands.

E-mail: jef.huisman@science.uva.nl

${ }^{3}$ These authors contributed equally to this work.

Received 12 May 2007; revised and accepted 15 June 2007; published online 12 July 2007 characteristic absorption spectrum (Pfennig, 1967; Falkowski and Raven, 1997; Des Marais, 2000; Xiong et al., 2000; Béjà et al., 2001; Falkowski et al., 2004). How can we explain the specific set of pigments that have evolved on planet Earth? Why is there not a single black pigment that absorbs all wavelengths?

Utilization of the light spectrum can be interpreted in terms of classical ecological theory. Light offers a spectrum of resources. According to ecological theory, niche differentiation along a resource spectrum reduces competition between species, and thereby promotes their coexistence (Gause, 1934; MacArthur and Levins, 1967; May and MacArthur, 1972; Rueffler et al., 2006). Darwin's finches on the Galápagos islands provide a famous example. Niche differentiation along a spectrum of different seed sizes allows a variety of finch species to coexist (Darwin, 1859; Lack, 1974; Grant and Grant, 2002). Likewise, differences in light absorption spectra of species result in niche differentiation along the light spectrum. Indeed, competition models and experiments have shown that red and green picocyanobacteria can coexist by absorbing different parts of the light spectrum (Stomp et al., 2004). 
Niche differentiation along the light spectrum is probably a common phenomenon in aquatic ecosystems. For instance, a recent field survey confirmed that the relative abundances of red and green picocyanobacteria in lakes and seas are related to the underwater light color (Stomp et al., 2007). Red picocyanobacteria dominate in relatively clear waters, where green light penetrates the deepest, while green picocyanobacteria dominate in turbid waters, where red light penetrates the deepest. Coexistence of red and green picocyanobacteria is widespread in waters of intermediate coloration. Likewise, many other studies have revealed a close correspondence between the absorption spectra of phototrophic microorganisms and the prevailing underwater light spectrum (for example, Pierson et al., 1990; Wood et al., 1998; Béjà et al., 2001; Vila and Abella, 2001; Rocap et al., 2003; Kühl et al., 2005; Bouman et al., 2006; Sabehi et al., 2007).

Which spectral niches are available for phototrophic microorganisms? If our planet would offer a continuum of spectral niches, then one would expect a free distribution of light absorption spectra along this continuum (as in Figure 1a). Alternatively, it might be that environmental conditions constrain part of the resource spectrum, such that only a few distinct niches are available (Figure 1b). In this paper, we show that vibrations of the water molecule create gaps in the underwater light spectrum. As a result, not all wavebands are equally available for photosynthesis. This yields a series of distinct spectral niches for phototrophic microorganisms.

\section{Vibrations of water molecules}

Water molecules are never at rest. They rotate and vibrate. Vibrations of water molecules occur in three modes, including symmetric stretching $\left(V_{1}\right)$, asymmetric stretching $\left(V_{3}\right)$ and bending $\left(V_{2}\right)$ of the water molecule (Figure 2a; see also, for example, Braun and Smirnov, 1993; Pegau et al., 1997; Sogandares and Fry, 1997). The energy for these vibrations is obtained by absorption of radiation. The vibrations are most intense at wavelengths matching the specific energy requirements of these motions. These wavelengths can be recognized as peaks in the absorption spectrum of pure water (Figure $2 \mathrm{~b}$ ). Because the energy requirements for symmetric and asymmetric stretching are rather similar, their absorption peaks coalesce into a large absorption peak at around $3000 \mathrm{~nm}$. The bending vibrations occur at a lower energy level, resulting in an absorption peak at around $6000 \mathrm{~nm}$. Harmonics of these vibrations occur at higher energy levels (that is, shorter wavelengths) that double or triple the required energy. As a result, harmonics of the bending and stretching vibrations can be recognized as shoulders in the visible and near-infrared range of the absorption spectrum of water. For instance, the distinct shoulders in Figure 2c, at 449, 514, 605, 742 and $972 \mathrm{~nm}$ have been identified as the seventh, sixth, fifth, fourth and third harmonics, respectively, of the symmetrical and asymmetrical stretch vibration (Braun and Smirnov, 1993; Pegau et al., 1997; Sogandares and Fry, 1997). The shoulder at $1130 \mathrm{~nm}$ has also been identified as a third harmonics, composed of the combination of a symmetrical, asymmetrical and bending vibration $\left(v_{1}+v_{2}+v_{3}\right)$. We will argue, below, that these subtle shoulders in the absorption spectrum of pure water have a major effect on the underwater light spectrum.

\section{The underwater light color}

The underwater light spectrum of aquatic ecosystems depends on light absorption by pure water as well as by other components, including dissolved organic matter (known as 'gilvin' in the optics literature), inanimate particulate organic matter (known as 'tripton') and phytoplankton. More specifically, according to Lambert-Beer's law the underwater light spectrum can be calculated as follows (Sathyendranath and Platt, 1989; Kirk, 1994; Stomp et al., 2007):

$$
I(\lambda, z)=I_{\text {in }}(\lambda) \operatorname{EXP}\left(-\left[K_{\mathrm{W}}(\lambda)+K_{\mathrm{GT}}(\lambda)+K_{\mathrm{PH}}(\lambda)\right] z\right)
$$

where $I(\lambda, z)$ is the light intensity of wavelength $\lambda$ at depth $z, I_{\text {in }}(\lambda)$ is the spectrum of the incident solar irradiance, $K_{\mathrm{w}}(\lambda)$ is the absorption spectrum of pure water (Figures 2b and c), $K_{\mathrm{GT}}(\lambda)$ is the absorption spectrum of gilvin and tripton and $K_{\mathrm{PH}}(\lambda)$ is a

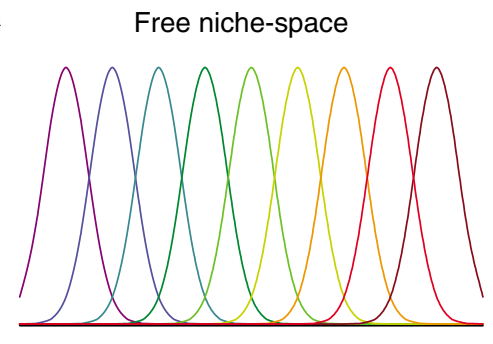

b

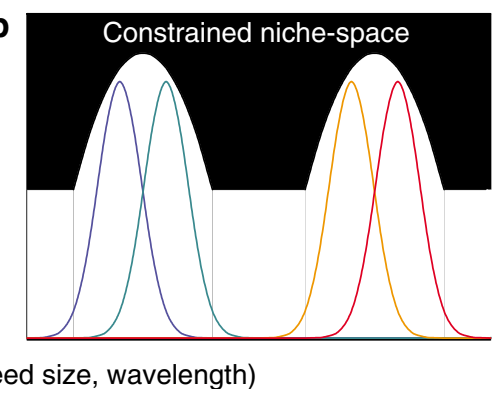

Figure 1 Resource utilization curves of competing species along a spectrum of resources. (a) Resources are freely distributed along the resource spectrum. (b) Environmental conditions impose constraints on the distribution of resources along the resource spectrum. 
a

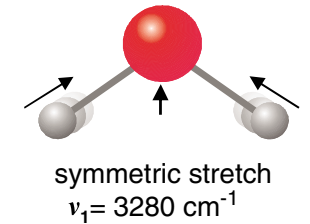

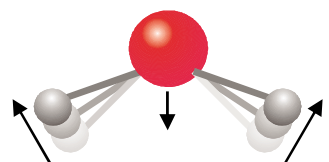

bend $v_{2}=1654 \mathrm{~cm}^{-1}$

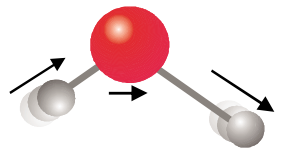

asymmetric stretch $v_{3}=3490 \mathrm{~cm}^{-1}$
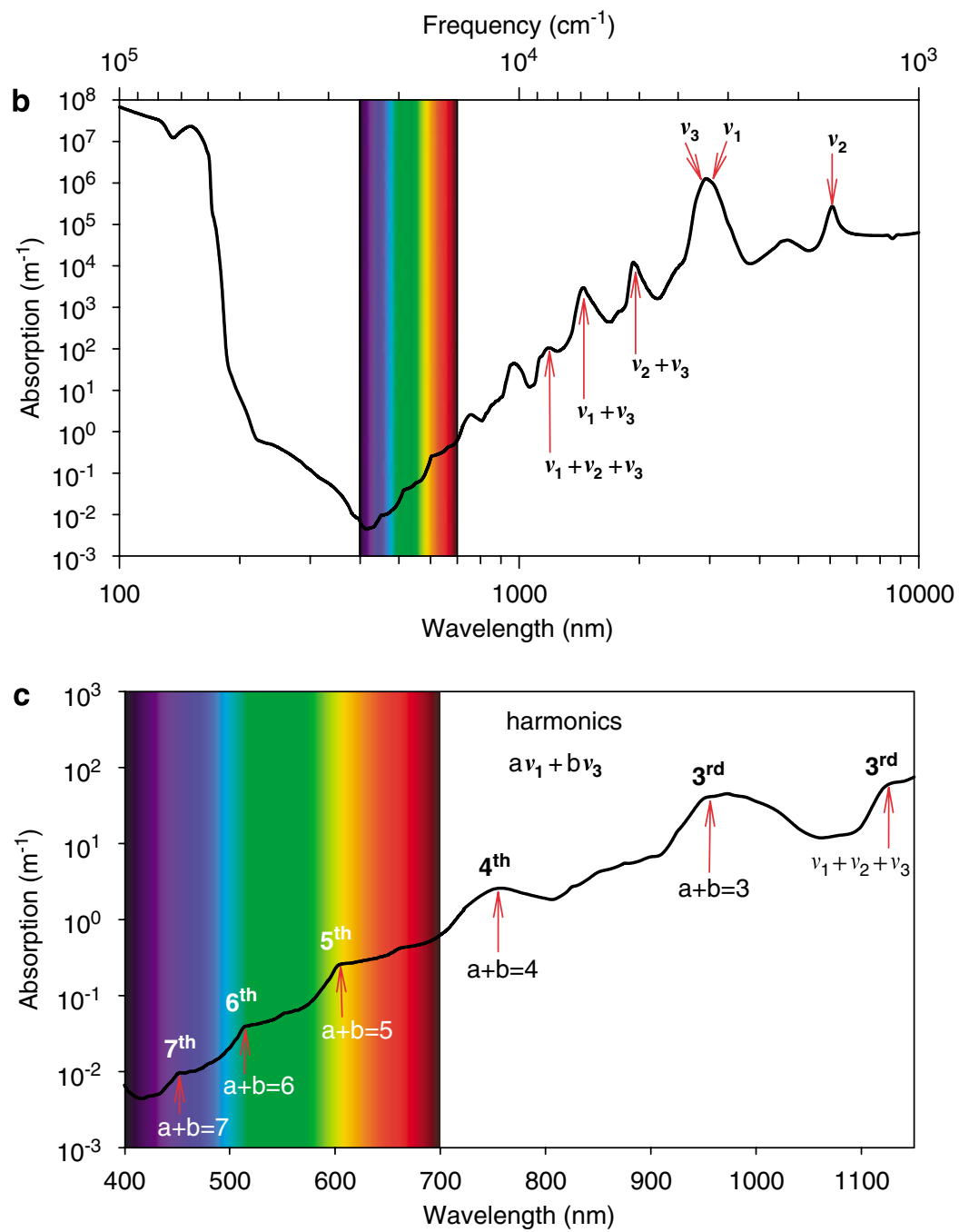

Figure 2 (a) The three vibrational modes of the water molecule and their fundamental frequencies in liquid water: symmetric stretching $\left(v_{1}\right)$, bending $\left(v_{2}\right)$ and asymmetric stretching $\left(v_{3}\right)$. The atoms move in the directions indicated by arrows. (b) Absorption spectrum of pure water (Hale and Querry, 1973; Segelstein, 1981; Pope and Fry, 1997). Peaks in the absorption spectrum correspond to the fundamental frequencies and higher harmonics of the vibrations of the water molecules. (c) Absorption spectrum of pure water in the visible and infrared region. Shoulders in the absorption spectrum correspond to the third, fourth, fifth, sixth and seventh harmonics of the symmetric and asymmetric stretch vibrations, as indicated.

the absorption spectrum of the phytoplankton community.

The incident solar irradiance has essentially a white spectrum with a few small dips from 450 to $900 \mathrm{~nm}$, and two large gaps in the infrared at 950 and $1120 \mathrm{~nm}$. These dips in the incident solar spectrum are due to light absorption by oxygen and water molecules in the atmosphere (Kirk, 1994). Pure water mainly absorbs red and infrared light, with several distinct shoulders (Figure 2c). In contrast, gilvin and tripton absorb strongly in the blue region of the spectrum (Figures 3a-c). More specifically, the absorption spectrum of gilvin and tripton is a decreasing function of wavelength, which can be described by a smoothly declining exponential curve (Bricaud et al., 1981; Kirk, 1994):

$$
K_{\mathrm{GT}}(\lambda)=K_{\mathrm{GT}}(440) \operatorname{EXP}(-S(\lambda-440))
$$

where $K_{\mathrm{GT}}(440)$ is the attenuation coefficient of gilvin and tripton at a reference wavelength of $440 \mathrm{~nm}$, and $S$ is the slope of the exponential decline. The attenuation coefficient $K_{\mathrm{GT}}(440)$ is 

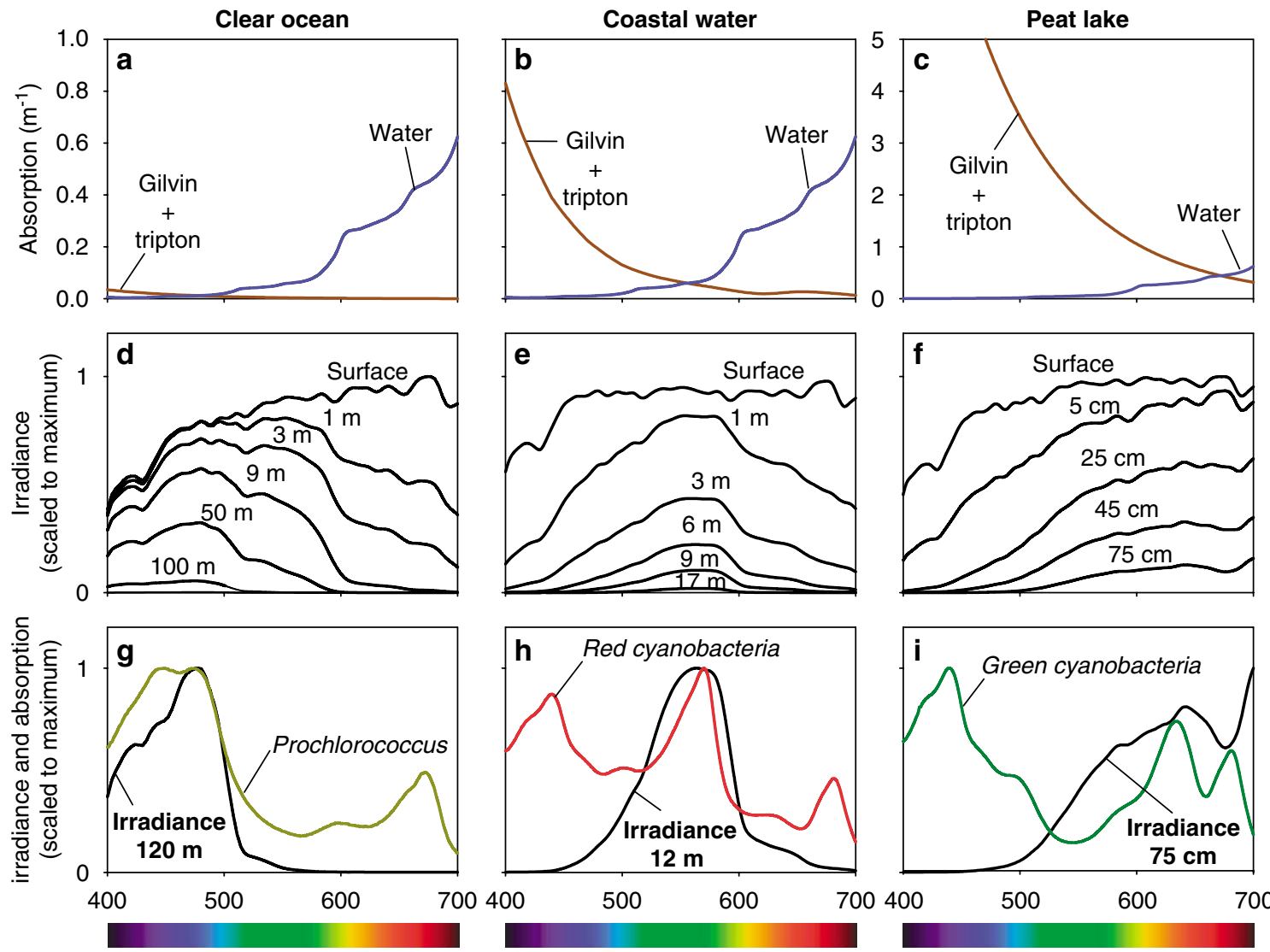

Wavelength $(\mathrm{nm})$

Figure 3 Underwater light spectra measured in the subtropical Pacific Ocean (station ALOHA), the coastal waters of the Baltic Sea (stations near the Gulf of Finland), and a peat lake in The Netherlands (Lake Groote Moost). (a-c) Light absorption spectra of pure water (blue line) and gilvin plus tripton (brown line). Note that light absorption by gilvin plus tripton is low in the Pacific Ocean, intermediate in the Baltic Sea and extremely high in Lake Groote Moost. (d-f) Underwater light spectra show that blue light penetrates very deep into the subtropical Pacific Ocean, green light penetrates deep into the Baltic Sea, while red light prevails in Lake Groote Moost. (g) The phytoplankton community sampled at $120 \mathrm{~m}$ depth in the subtropical Pacific Ocean was dominated by low-light adapted Prochlorococcus, which strongly absorb the available blue light using the pigments divinyl-chlorophyll $a$ and $b$ (absorption band at $450-500 \mathrm{~nm}$ ). (h) The phytoplankton community sampled at $12 \mathrm{~m}$ depth in the Baltic Sea was dominated by red-colored Synechococcus strains, which strongly absorb the available green light using the pigment phycoerythrin. (i) The phytoplankton community sampled at $75 \mathrm{~cm}$ depth in Lake Groote Moost was dominated by green cyanobacteria and green algae, which strongly absorb the available red light (absorption peaks of phycocyanin at $635 \mathrm{~nm}$ and chlorophyll $a$ at $680 \mathrm{~nm}$ ). Materials and methods for these measurements are described in the Supplementary Information.

proportional to the concentration of gilvin and tripton.

In waters with low concentrations of gilvin and tripton and low phytoplankton concentrations, light absorption by pure water dominates (for example, Kirk, 1994; Morel et al., 2007). This applies, for instance, to the oligotrophic waters of the subtropical Pacific Ocean (Figure 3a). Here, red light is absorbed by water within the upper $10 \mathrm{~m}$, whereas blue light penetrates much deeper (Figure 3d). Indeed, selective absorption of red light is responsible for the blue color of the oceans of our planet. In coastal waters, like the Baltic Sea, gilvin and tripton concentrations are higher, and their light absorption is often of a similar magnitude as light absorption by water itself (Figure 3b). As a result, green light penetrates the deepest (Figure 3e). In peat lakes, gilvin and tripton concentrations are extremely high, such that blue and green lights are rapidly absorbed (Figure 3c). As a result, red light penetrates the deepest (Figure 3f). Hence, with increasing gilvin and tripton concentrations, the underwater light color is shifted from the blue part towards the green and red part of the spectrum.

To investigate in further detail how gilvin concentrations affect the underwater light spectrum, we measured the underwater light spectrum in a variety of different aquatic ecosystems, ranging from blue waters of the Pacific Ocean to brown waters of very humic lakes. In addition, we searched the literature for light spectra measured in microbial mats, and found a beautiful spectrum from the murky microbial mats surrounding Rabbit Creek Spouter in Yellowstone National Park (Boomer et al., 2000). Figure 4 shows graphical plots of the underwater light spectra measured at the euphotic depth. The euphotic depth is here defined as the depth at which the irradiance over the entire photosynthetically 


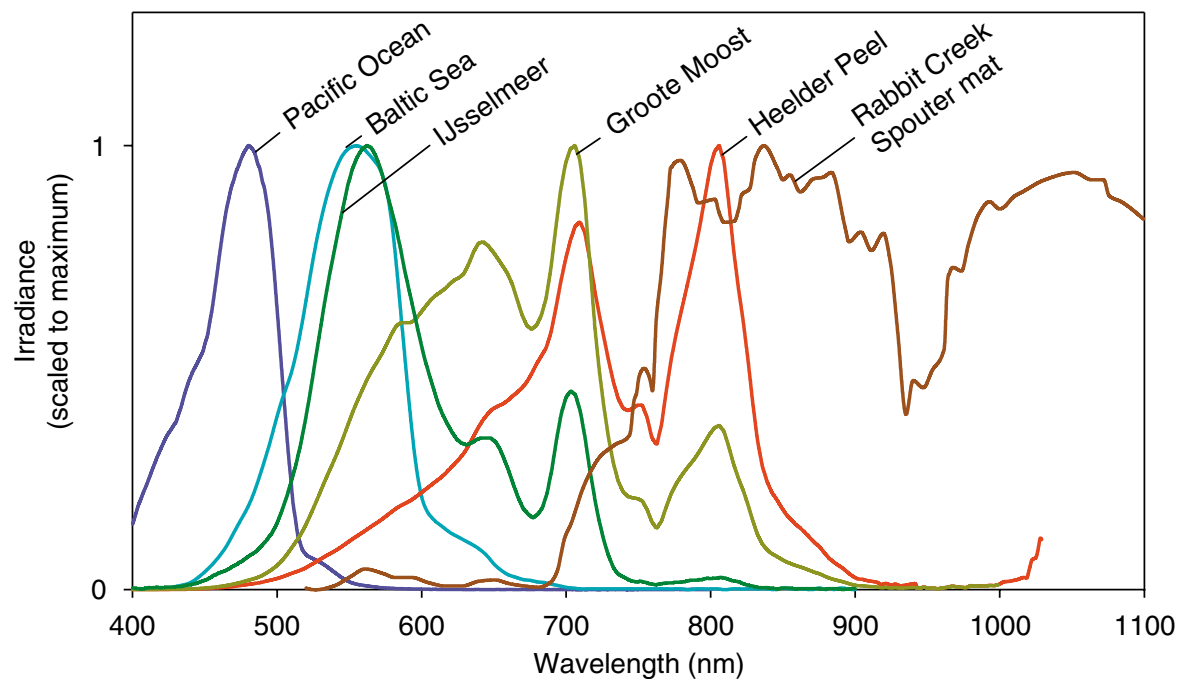

Figure 4 Underwater light spectra measured at the euphotic depth of six aquatic ecosystems. These ecosystems span the entire range from very clear waters with low gilvin and tripton concentrations in the subtropical Pacific Ocean to extremely turbid conditions in the microbial mat of Rabbit Creek Spouter (a hot spring in Yellowstone National Park). Euphotic depths vary accordingly, from 120 m in the clear blue waters of the subtropical Pacific Ocean to less than a few millimeters in the microbial mat. Materials and methods for these measurements are described in the Supplementary Information. The irradiance spectrum of the Rabbit Creek Spouter mat is from Boomer et al. (2000).

available spectrum for aquatic microorganisms (400-1100 nm) equals $1 \%$ of the irradiance at the water surface. With increasing gilvin and tripton concentration, the underwater light color is shifted towards the red and even the infrared region of the spectrum in Lake Groote Moost, Lake Heelder Peel and the Rabbit Creek Spouter mat. Surprisingly, the data do not show a smooth shift in the underwater light spectrum, but reveal a striking landscape of peaks and valleys (Figure 4). Some underwater light spectra consist of a single peak, like the spectra of the Pacific Ocean and the Baltic Sea. Other underwater light spectra display several peaks and valleys. Moreover, the same peaks and valleys reoccur in different aquatic ecosystems. For instance, Lake IJsselmeer shows a similar peak at $560 \mathrm{~nm}$ as the Baltic Sea, and shares two peaks at 640 and $700 \mathrm{~nm}$ with Lake Groote Moost. Lake Groote Moost and Lake Heelder Peel share conspicuous peaks at both 700 and $800 \mathrm{~nm}$, separated by a deep valley at 740-760 nm (Figure 4). The spectrum of the Rabbit Creek Spouter mat partly overlaps with Lake Heelder Peel, and extends further into the infrared, with a large dip at around $935 \mathrm{~nm}$. If the absorption spectrum of gilvin and tripton is a smoothly decreasing function of wavelength (equation (2)), then why do underwater light spectra produce such a striking landscape of peaks and valleys?

\section{Small shoulders, large gaps}

The spectrum of the incident solar irradiance (Figure 5a) might offer a possible explanation for the striking landscape of peaks and valleys in the underwater light spectra of Figure 4. However, according to equation (1), peaks and valleys in the solar spectrum are transferred linearly in the underwater light spectrum. That is, the peaks and valleys in the solar spectrum are not amplified with depth. Therefore, only major gaps in the solar spectrum can be recognized in underwater light spectra. For example, the sharp dip in the solar light spectrum at $765 \mathrm{~nm}$, due to atmospheric oxygen (Figure 5a), can be recognized in the underwater light spectra of Lake Groote Moost and Lake Heelder Peel. Similarly, the major gap in the solar light spectrum at $935 \mathrm{~nm}$, due to atmospheric water, can be recognized in the irradiance spectrum of the Rabbit Creek Sprouter mat. The remainder of the solar spectrum in the range of $450-1100 \mathrm{~nm}$ is rather flat, however, and does not bear any resemblance with the measured underwater light spectra (compare Figures 4 and 5a).

The subtle shoulders in the light absorption spectrum of pure water (Figure 5b) may offer an alternative explanation for the striking landscape of peaks and valleys in Figure 4. According to equation (1), subtle shoulders in the light absorption spectrum of water are amplified with depth. That is, consider two wavelengths, $\lambda_{1}$ and $\lambda_{2}$. For simplicity, assume that there is a subtle difference in light absorption by water at these two wavelengths, while the incident irradiance and light attenuation by other components would be equal for $\lambda_{1}$ and $\lambda_{2}$. Now, according to equation (1), the light intensities at these two wavelengths will diverge exponentially with depth:

$$
\frac{I\left(\lambda_{1}, z\right)}{I\left(\lambda_{2}, z\right)}=\operatorname{EXP}\left(\left[K_{\mathrm{W}}\left(\lambda_{2}\right)-K_{\mathrm{W}}\left(\lambda_{1}\right)\right] z\right)
$$

This shows that, due to the exponential nature of light absorption, subtle shoulders in the absorption 


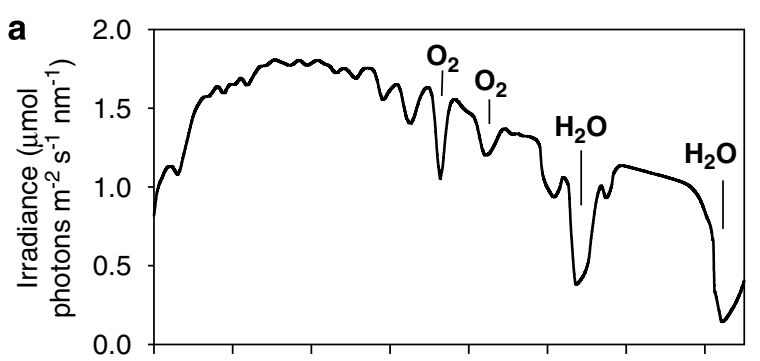

b

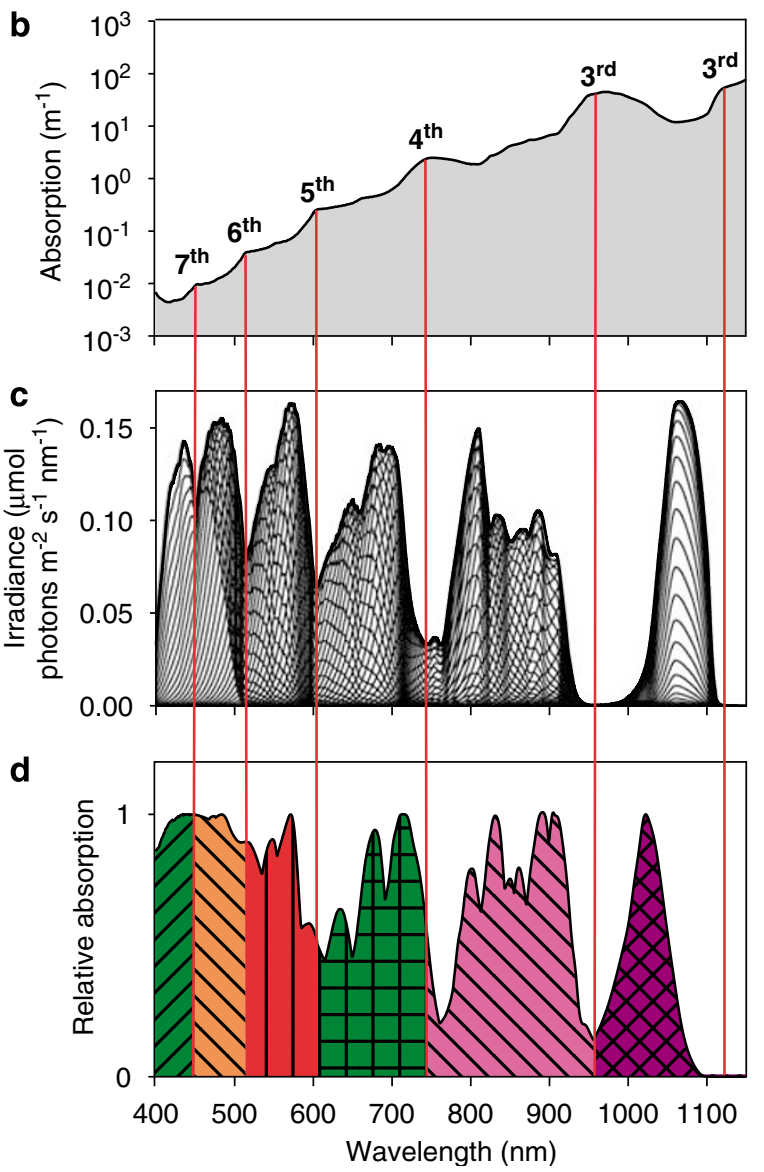

Figure 5 The absorption spectrum of water creates a series of distinct niches in the underwater light spectrum. (a) Light spectrum of the incident solar irradiance at the water surface. Dips in the incident irradiance are caused by absorption of photons by oxygen and water molecules in the atmosphere. (b) Absorption spectrum of pure water, plotted at a log scale. The different harmonics of the stretching and bending vibrations of the water molecule are indicated. (c) Overlay of 100 underwater light spectra at the euphotic depth. The light spectra are calculated from equations 1 and 2, using a wide range of different gilvin and tripton concentrations, from the clearest ocean waters to very turbid systems such as microbial mats. (d) Overlay of measured light absorption spectra of 20 phototrophic species, including purple sulfur bacteria, green sulfur bacteria, purple non-sulfur bacteria, cyanobacteria, green algae, red algae, diatoms and chrysophytes. Light absorption spectra of each individual species are shown in Figure 6.

spectrum of water create large gaps in the underwater light spectrum.

To investigate the latter hypothesis in further detail, we calculated the underwater light spectrum in the absence of phytoplankton. In this way, we obtained the available niches in the underwater light spectrum that can be exploited as a potential playfield for the ecology and evolution of phototrophic microorganisms. More specifically, we used equations (1) and (2) to calculate 100 different underwater light spectra at the euphotic depth. The absorption spectrum of pure water was taken from the literature (Hale and Querry, 1973; Segelstein, 1981; Pope and Fry, 1997). The slope $S$ in equation (2) typically varies between 0.010 and $0.020 \mathrm{~nm}^{-1}$, and we here assumed a typical value of $S=0.017 \mathrm{~nm}^{-1}$ (Kirk, 1994). The calculations were made for a wide range of different gilvin and tripton concentrations, with $K_{\mathrm{GT}}(440)$ values from $0.003 \mathrm{~m}^{-1}$ in very clear ocean waters (Morel et al., 2007) to more than $5000 \mathrm{~m}^{-1}$ in extremely turbid systems representative for microbial mats in sediments (Kühl and Jørgensen, 1994). As a consequence, the euphotic depths ranged from more than $200 \mathrm{~m}$ in clear ocean water to only a few $\mathrm{mm}$ in turbid sediments and microbial mats.

Figure 5c shows an overlay of all 100 underwater light spectra thus calculated, which reveals a landscape of peaks and valleys quite similar to the measured underwater light spectra in Figure 4. Comparison of Figures 5a and c show that the dips in solar irradiance have some effect on the underwater light spectra, but this effect is relatively small. For instance, the dip caused by atmospheric oxygen at $765 \mathrm{~nm}$ (Figure 5a) creates a small secondary valley in the calculated underwater light spectra (Figure 5c). This small secondary valley was also visible in the measured light spectra of Lake Groote Moost and Lake Heelder Peel (Figure 4). In contrast, our calculations show that, consistent with equation (3), the subtle shoulders in the absorption spectrum of water create large gaps in the underwater light spectrum. The shoulder of the sixth harmonics in the absorption spectrum of water (Figure 5b) creates a large gap in the underwater light spectrum at $\sim 514 \mathrm{~nm}$ (Figure 5c). This gap separates the measured underwater light spectra of the Pacific Ocean and the Baltic Sea (Figure 4). Likewise, the shoulder at the fifth harmonics in the absorption spectrum of pure water (Figure 5b) creates a gap in the underwater light spectrum at $\sim 600 \mathrm{~nm}$ (Figure 5c), which separates the measured underwater light spectra of the Baltic Sea and Lake IJsselmeer from the peaks of Lake Groote Moost and Lake Heelderpeel (Figure 4). The next shoulder in the absorption spectrum of pure water, at the fourth harmonics (Figure 5b), creates a large gap in the underwater light spectrum at $740-760 \mathrm{~nm}$ (Figure 5c). This corresponds to the gap within the measured underwater light spectra of Lake Groote Moost and Lake Heelder Peel (Figure 4). Finally, at $\sim 950 \mathrm{~nm}$, the combination of a deep trough in the incident solar irradiance caused by water molecules in the atmosphere (Figure 5a) and a large shoulder at the third harmonics of liquid water (Figure 5b) create a deep gap in the underwater light spectrum (Figure 5c). This gap can be clearly 
Table 1 Phototrophic organisms mentioned in Figures 5d and 6

\begin{tabular}{|c|c|c|c|}
\hline Number & Species & Main pigments & Reference \\
\hline & \multicolumn{3}{|l|}{ Green sulfur bacteria } \\
\hline 1 & Pelodictyon phaeoclathratiforme & BChl $e$ & Overmann and Pfennig, 1989 \\
\hline 2 & Prosthecochloris aestuarii & BChl $a, c$ & Overmann et al., 1991 \\
\hline & \multicolumn{3}{|l|}{ Purple sulfur bacteria } \\
\hline 3 & Thiocapsa marina & BChl $a$ & Caumette et al., 2004 \\
\hline 4 & Thiocapsa roseopersicina & BChl $a$ & Caumette et al., 2004 \\
\hline 5 & Chromatium okenii & BChl $a$ & Pfennig, 1967 \\
\hline & \multicolumn{3}{|l|}{ Purple non-sulfur bacteria } \\
\hline 6 & Rhodobacter capsulatus & BChl $a$ & Zubova et al., 2005 \\
\hline 7 & Rhodobacter sphaeroides & BChl $a$ & This study \\
\hline 8 & Rhodospirillum rubrum & BChl $a$ & Pfennig, 1967 \\
\hline 9 & Roseospirillum parvum & BChl $a$ & Glaeser and Overmann, 1999 \\
\hline 10 & Blastochloris viridis & BChl $b$ & Pfennig, 1967 \\
\hline & \multicolumn{3}{|l|}{ Cyanobacteria } \\
\hline 11 & Prochlorococcus sp. & Divinyl-Chl $a, b$ & This study \\
\hline 12 & Synechococcus WH7803 & Chl $a$, PUB/PEB & Toledo et al., 1999 \\
\hline 13 & Synechococcus WH8103 & Chl $a$, PUB/PEB & Toledo et al., 1999 \\
\hline 14 & Synechococcus BS5 & Chl $a, \mathrm{PC}, \mathrm{PE}$ & This study \\
\hline 15 & Synechococcus BS4 & Chl $a, \mathrm{PC}$ & This study \\
\hline 16 & Acaryochloris marina & Chl $d$ & Kühl et al., 2005 \\
\hline & \multicolumn{3}{|l|}{ Green algae } \\
\hline 17 & Chlamydomonas sp. & Chl $a, b$ & This study \\
\hline & \multicolumn{3}{|l|}{ Diatoms } \\
\hline 18 & Phaeodactylum tricornutum & Chl $a$ & This study \\
\hline & \multicolumn{3}{|l|}{ Chrysophytes } \\
\hline 19 & Isochrysis sp. & Chl $a$ & This study \\
\hline & \multicolumn{3}{|l|}{ Red algae } \\
\hline 20 & Palmaria palmata & Chl $a, \mathrm{PE}$ & Cordi et al., 1997 \\
\hline
\end{tabular}

Abbreviations: BChl, bacteriochlorophyll; Chl, chlorophyll; PC, phycocyanin; PE, phycoerythrin; PEB, phycoerythrobilin; PUB, phycourobilin.

recognized in the irradiance spectra of microbial mats (Pierson et al., 1990; Boomer et al., 2000), as exemplified by the Rabbit Creek Spouter mat (Figure 4). In other words, this exercise shows that the underwater light spectrum does not present a homogeneous playfield for the ecology and evolution of phototrophic microorganisms. Instead, the underwater light spectrum offers a number of distinct niches at specific wavebands, separated by deep gaps created by the shoulders in the light absorption spectrum of the water molecule.

\section{Filling the niches}

Have phototrophic microorganisms adapted the absorption spectra of their pigments to these distinct niches in the underwater light spectrum? Three examples are provided in Figure 3. The phytoplankton community in the subtropical Pacific Ocean is dominated by picocyanobacteria of the genus Prochlorococcus (Chisholm et al., 1988; Letelier et al., 1993). Prochlorococcus effectively absorbs the available blue light with its pigments divinyl-chlorophyll $a$ and $b$ (Figure 3g). In the Baltic Sea, the phytoplankton community at the euphotic depth is dominated by red-colored picocyanobacteria of the Synechococcus group (Stomp et al., 2007), which effectively absorb the available green light with their pigment phycoerythrin (Figure $3 \mathrm{~h}$ ). In peat lakes, the phytoplankton community is often dominated by green-colored phytoplankton species, like green cyanobacteria and green algae, which absorb the available red light with pigments such as phycocyanin and chlorophylls $a$ and $b$ (Figure 3i). This is a first indication that the light absorption spectra of phytoplankton communities are often well tuned to their underwater light environment.

To extend our analysis to the full light spectrum available for photosynthesis, from 400 to $1100 \mathrm{~nm}$, we gathered absorption spectra of 20 phototrophic species containing a wide variety of different pigments. The species belong to the green sulfur bacteria, purple sulfur bacteria, purple non-sulfur bacteria, cyanobacteria, green algae, diatoms, chrysophytes and red algae (Table 1). We measured the light absorption spectra of seven species with an Aminco DW-2000 double-beam spectrophotometer. Light absorption spectra of the other 13 species were obtained from the literature (Table 1). The absorp- 

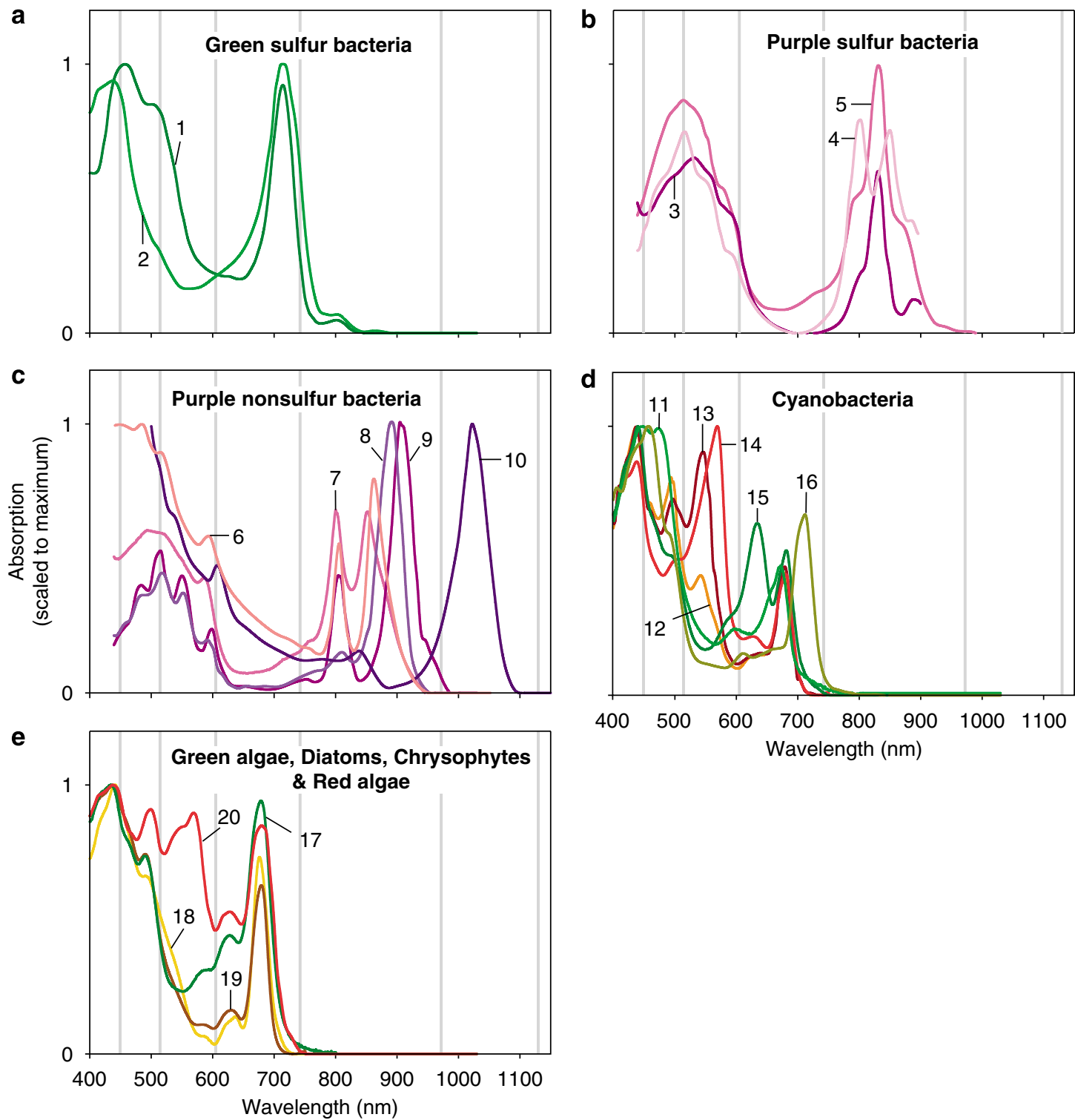

Figure 6 In vivo absorption spectra of intact cells of 20 phototrophic species, including purple sulfur bacteria, green sulfur bacteria, purple non-sulfur bacteria, cyanobacteria, green algae, red algae, diatoms and chrysophytes. The names of the species and their main photosynthetic pigments are listed in Table 1. Vertical lines indicate the location of the harmonics of the stretching and bending vibrations of the water molecule.

tion spectra of the individual species are shown in Figure 6. An overlay of all 20 absorption spectra is shown in Figure 5d. The match between the peaks and valleys in the underwater light spectrum and the peaks and valleys in the light absorption spectra of this rich variety of photosynthetic pigments is striking. That is, the harmonics in the light absorption spectrum of pure water (Figure $5 \mathrm{~b}$ ) create a series of distinct niches in the underwater light spectrum (Figure 5c), which are effectively captured by the light absorption spectra of the major groups of phototrophic microorganisms inhabiting our planet (Figure 5d).

Peaks in the underwater light spectrum at wavelengths below the sixth harmonics $(<514 \mathrm{~nm})$ are captured by chlorophyll $a$ and $b$, divinyl-chloro- phylls $a$ and $b$ and accessory carotenoids. The peak in the underwater light spectrum between the sixth and fifth harmonics (514-604 nm) is captured by the phycoerythrins of red algae and cyanobacteria. Peaks in the underwater light spectrum between the fifth and fourth harmonics $(604-760 \mathrm{~nm})$ are captured by phycocyanin, chlorophylls $a, b$ and $d$, and bacteriochlorophyll e. Bacteriochlorophyll $a$ in various phototrophic bacteria captures the peaks in the underwater light spectrum between the fourth and third harmonics (760-960 nm). Finally, bacteriochlorophyll $b$ in the purple bacterium Blastochloris viridis (formerly known as Rhodopseudomonas viridis) harvests the light energy available at wavelengths between both third harmonics (960-1130 nm). Interestingly, the absorption peak of $B$. viridis seems to be 
shifted a bit towards shorter wavelengths compared to its spectral niche (compare Figures $5 \mathrm{c}$ and d). Perhaps our model calculations do not provide a very accurate description of spectral niches in microbial mats, where scattering of light can play an important role (Pierson et al., 1990). Furthermore, the infrared part of the light absorption spectrum of water is sensitive to temperature (Collins, 1925; Braun and Smirnov, 1993), which may shift this spectral niche to slightly shorter wavelengths at high temperatures. Also, the exact location of the light absorption peak of $B$. viridis is probably sensitive to temperature, and the range of measurements on lab cultures may not be exactly the same as in the bacterium's native environment (Kiang et al., 2007). It would be interesting to investigate these issues further. Perhaps other species containing bacteriochlorophyll $b$ are capable to harvest light at even longer wavelengths, and therefore match this infrared niche more closely.

\section{Discussion}

In this paper, we have developed the hypothesis that vibrations of the water molecule generate a series of distinct niches in the underwater light spectrum, which are effectively utilized by the different phototrophic microorganisms inhabiting our planet.

Our hypothesis implicitly assumes that the underwater light spectrum is an important selective factor for the ecology and evolution of phototrophic microorganisms. This hypothesis is supported by several lines of evidence. Many physiological studies have shown that light color affects photosynthesis and growth rates of phototrophic microorganisms, as has been demonstrated for, for example, green sulfur bacteria (Montesinos et al., 1983; Vila and Abella, 1994), cyanobacteria (Wyman and Fay, 1986; Hauschild et al., 1991; Callieri et al., 1996) and eukaryotic phytoplankton (Holdsworth, 1985; Glover et al., 1987). Furthermore, laboratory competition experiments have shown that light color can act as a selective factor. For instance, Parkin and Brock (1980) studied competition between green and purple sulfur bacteria isolated from the sulfide containing waters of three stratified lakes with different underwater light spectra. They observed that green sulfur bacteria became dominant in flasks exposed to red light, whereas purple sulfur bacteria became dominant in flasks exposed to green light. Likewise, Stomp et al. (2004) studied competition between red and green picocyanobacteria isolated from the Baltic Sea. They developed a competition model that predicts that red picocyanobacteria should become dominant in green light, green picocyanobacteria should become dominant in red light, whereas red and green picocyanobacteria can coexist in the full spectrum provided by white light. The results of their competition experiments were consistent with these predictions. These studies demonstrated that light color plays a decisive role in the species composition of phototrophic communities, at least in controlled laboratory experiments.

Numerous field studies have confirmed that the species composition of phototrophic microorganisms is related to the underwater light spectrum. For instance, Figure 3 shows that Prochlorococcus in the subtropical Pacific Ocean is well tuned to the prevailing blue light, red picocyanobacteria in the Baltic Sea are well tuned to the prevailing green light, and green cyanobacteria and green algae in turbid waters are well tuned to the prevailing red light. Recent work has shown that the relative abundances of red and green picocyanobacteria show a clear link with the underwater light spectrum across many ecosystems (Stomp et al., 2007). Likewise, the relative abundances of proteorhodopsin containing bacteria absorbing either blue or green light have been explained by prevailing spectral light conditions (Béjà et al., 2001; Sabehi et al., 2007). Similar observations have shown a good correspondence between the absorption spectra of phototrophic microorganisms and the underwater light spectrum in clear oceans (Ting et al., 2002; Rocap et al., 2003; Bouman et al., 2006), coastal waters (Olson et al., 1990; Wood et al., 1998; Katano et al., 2007), lakes (Pick, 1991; Vörös et al., 1998; Vila and Abella, 2001) and microbial mats (Pfennig, 1967; Pierson et al., 1990; Kühl et al., 2005). Thus, there is overwhelming evidence from theory, laboratory experiments and field data that the underwater light spectrum is a major determinant of the species composition of phototrophic communities.

The novel part of our hypothesis is that the underwater light spectrum does not offer a continuum of niches (as in Figure 1a), but consists of a series of distinct niches (as in Figure 1b) created by vibrations of the water molecule. This rather unexpected prediction is supported by the striking similarity between the calculated peaks and valleys in the underwater light spectra (Figure 5c) and the observed peaks and valleys in the absorption spectra of phototrophic microorganisms (Figure 5d). That is, the absorption spectra of the major photosynthetic pigments fit the available niches in the underwater light spectrum. Moreover, each spectral niche can be occupied by several pigments, with slightly different absorption peaks. For example, the niche between the sixth and fifth harmonics is occupied by two types of phycoerythrin, known as phycourobilin (PUB; peak at $494 \mathrm{~nm}$ ) and phycoerythrobilin (PEB; peak at $545 \mathrm{~nm}$ ) (Toledo et al., 1999). Likewise, several variants of bacteriochlorophyll $a$ cover the niche between the fourth and third harmonics. This indicates that, within each spectral niche, absorption peaks of phototrophic organisms may diverge, possibly driven by the evolutionary process of adaptive radiation (Schluter, 2000; Rueffler et al., 2006).

Yet, this part of our hypothesis is clearly open for further testing. For instance, laboratory competition 
experiments could simulate light environments that deviate from the underwater light niches predicted by our model. As a first test, mixtures of phototrophic microorganisms could be exposed to wavebands that are less available in underwater light spectra. For example, wavelengths around $600 \mathrm{~nm}$ are relatively less available due to strong absorption by the fifth harmonics of water (Figure 5c), and currently few microorganisms have their absorption peak at $600 \mathrm{~nm}$ (Figure 6). If this waveband becomes the prevailing light color in a long-term laboratory selection experiment, will selection favor new mutants that shift their absorption peak to $600 \mathrm{~nm}$ ?

Another interesting test could be based on selection experiments in artificial water that lacks the characteristic absorption peaks of normal water $\left(\mathrm{H}_{2} \mathrm{O}\right)$. In so-called heavy water $\left(\mathrm{D}_{2} \mathrm{O}\right)$, the hydrogen atoms are replaced by heavier deuterium atoms. As a consequence, molecular vibrations of $\mathrm{D}_{2} \mathrm{O}$ occur at other frequencies, and the harmonics of heavy water molecules are shifted to the far-red compared to $\mathrm{H}_{2} \mathrm{O}$. Hence, the absorption spectrum of $\mathrm{D}_{2} \mathrm{O}$ is completely different from that of $\mathrm{H}_{2} \mathrm{O}$ (Tam and Patel, 1979; Braun and Smirnov, 1993). Our hypothesis therefore predicts that, in light-limited systems, selection experiments in $\mathrm{D}_{2} \mathrm{O}$ will lead to phototrophic communities with other light absorption spectra than selection experiments in $\mathrm{H}_{2} \mathrm{O}$.

In conclusion, our findings point at a striking causal relationship between the stretching and bending vibrations of the water molecule, the underwater light spectra of aquatic ecosystems and the ecology and evolution of phototrophic microorganisms.

\section{Acknowledgements}

We thank M Laamanen and DM Karl for the opportunity to join cruise Cyano-04 on the Baltic Sea and HOT cruise 174 on the Pacific Ocean, and the crew of research vessels Aranda and Kilo Moana for their great help during sampling. We also thank B Pex, H van Overzee, R Poutsma and students of the MSc program Limnology \& Oceanography 2005 for their help in the Dutch lakes, and HJ Gons and JC Kromkamp for the underwater light spectrum of Lake IJsselmeer, and their help with the filterpad method. Special thanks to $\mathrm{O}$ Béjà and the anonymous referee for their helpful comments on the manuscript. The research of MS and $\mathrm{JH}$ was supported by the Earth and Life Sciences Foundation (ALW), which is subsidized by the Netherlands Organization for Scientific Research (NWO). LJS acknowledges support from the European Commission through the project MIRACLE (EVK3-CT-2002-00087).

\section{References}

Béjà O, Spudich EN, Spudich JL, Leclerc M, DeLong EF. (2001). Proteorhodopsin phototrophy in the ocean. Nature 411: 786-789.

Boomer SM, Pierson BK, Austinhirst R, Castenholz RW. (2000). Characterization of novel bacteriochlorophyll- $a$-containing red filaments from alkaline hot springs in Yellowstone National Park. Arch Microbiol 174: 152-161.

Bouman HA, Ulloa O, Scanlan DJ, Zwirglmaier K, Li WKW, Platt T et al. (2006). Oceanographic basis of the global surface distribution of Prochlorococcus ecotypes. Science 312: 918-921.

Braun CH, Smirnov SN. (1993). Why is water blue? J Chem Edu 70: 612-614.

Bricaud A, Morel A, Prieur L. (1981). Absorption by dissolved organic matter of the sea (yellow substance) in the UV and visible domains. Limnol Oceanogr 26: 43-53.

Callieri C, Amicucci E, Bertoni R, Vörös L. (1996). Fluorometric characterization of two picocyanobacteria strains from lakes of different underwater light quality. Int Revue Ges Hydrobiol 81: 13-23.

Caumette P, Guyoneaud R, Imhoff JF, Süling J, Gorenko V. (2004). Thiocapsa marina sp. nov. a novel, okenonecontaining, purple sulfur bacterium isolated from brackish coastal and marine environments. Int J Syst Evol Microbiol 54: 1031-1036.

Chisholm SW, Olson RJ, Zettler ER, Goericke R, Waterbury JB, Welschmeyer NA. (1988). A novel free-living prochlorophyte abundant in the oceanic euphotic zone. Nature 334: 340-343.

Collins JR. (1925). Change in the infra-red absorption spectrum of water with temperature. Phys Rev 26: 771-779.

Cordi B, Depledge MH, Price DN, Salter LF, Donkin ME. (1997). Evaluation of chlorophyll fluorescence, in vivo spectrophotometric pigment absorption and ion leakage as biomarkers of UV-B exposure in marine macroalgae. Mar Biol 130: 41-49.

Darwin CR. (1859). On the Origin of Species by Means of Natural Selection. John Murray: London.

Des Marais DJ. (2000). Evolution-when did photosynthesis emerge on earth? Science 289: 1703-1705.

Engelmann TW. (1882). Über Sauerstoffausscheidung von Pflanzenzellen im Mikrospectrum. Bot Zeit 40: 419-426.

Engelmann TW. (1883). Bacterium photometricum: ein Beitrag zur vergleichenden Physiologie des Licht- und Farbensinnes. Archiv Physiol 30: 95-124.

Falkowski PG, Katz ME, Knoll AH, Quigg A, Raven JA, Schofield $\mathrm{O}$ et al. (2004). The evolution of modern eukaryotic phytoplankton. Science 305: 354-360.

Falkowski PG, Raven JA. (1997). Aquatic Photosynthesis, 2nd edn. Blackwell Science: London, UK.

Gause GF. (1934). The Struggle for Existence. Williams and Wilkins: Baltimore, MD.

Glaeser J, Overmann J. (1999). Selective enrichment and characterization of Roseospirillum parvum, gen. nov. and sp. nov., a new purple nonsulfur bacterium with unusual light absorption properties. Arch Microbiol 171: 405-416.

Glover HE, Keller MD, Spinrad RW. (1987). The effects of light quality and intensity on photosynthesis and growth of marine eukaryotic and prokaryotic phytoplankton clones. J Exp Mar Biol Ecol 105: 137-159.

Grant PR, Grant BR. (2002). Adaptive radiation of Darwin's finches. Am Sci 90: 130-139.

Hale GM, Querry MR. (1973). Optical constants of water in the $200-\mathrm{nm}$ to $200-\mu \mathrm{m}$ wavelength region. Appl Opt 12: $555-563$. 
Hauschild CA, McMurter HJG, Pick FR. (1991). Effect of spectral quality on growth and pigmentation of picocyanobacteria. J Phycol 27: 698-702.

Holdsworth ES. (1985). Effects of growth factors and light quality on the growth, pigmentation and photosynthesis of two diatoms, Thalassiosira gravida and Phaeodactylum tricornutum. Mar Biol 86: 253-262.

Katano T, Kaneda A, Kanzaki N, Obayashi Y, Morimoto A, Onitsuka G et al. (2007). Distribution of prokaryotic picophytoplankton from Seto Inland Sea to the Kuroshio region, with special reference to 'Kyucho' events. Aquat Microb Ecol 46: 191-201.

Kiang NY, Siefert J, Govindjee, Blankenship RE. (2007). Spectral signatures of photosynthesis. I. Review of Earth organisms. Astrobiology 7: 222-251.

Kirk JTO. (1994). Light and Photosynthesis in Aquatic Ecosystems, 2nd edn. Cambridge University Press: Cambridge, UK.

Kühl M, Chen M, Ralph PJ, Schreiber U, Larkum AWD. (2005). A niche for cyanobacteria containing chlorophyll $d$. Nature 433: 820.

Kühl M, Jørgensen BB. (1994). The light field of microbenthic communities: radiance distribution and microscale optics of sandy coastal sediments. Limnol Oceanogr 39: 1368-1398.

Lack D. (1974). Darwin's Finches. Cambridge University Press: Cambridge, UK.

Letelier RM, Bidigare RR, Hebel DV, Ondrusek M, Winn CD, Karl DM. (1993). Temporal variability of phytoplankton community structure based on pigment analysis. Limnol Oceanogr 38: 1420-1437.

MacArthur R, Levins R. (1967). The limiting similarity, convergence, and divergence of coexisting species. Am Nat 101: 377-385.

May RM, MacArthur RH. (1972). Niche overlap as a function of environmental variability. Proc Natl Acad Sci USA 69: 1109-1113.

Montesinos E, Guerrero R, Abella C, Esteve I. (1983). Ecology and physiology of the competition for light between Chlorobium limicola and Chlorobium phaeobacteroides in natural habitats. Appl Environ Microbiol 46: 1007-1016.

Morel A, Gentili B, Claustre H, Babin M, Bricaud A, Ras J et al. (2007). Optical properties of the 'clearest' natural waters. Limnol Oceanogr 52: 217-229.

Olson RJ, Chisholm SW, Zettler ER, Armbrust EV. (1990). Pigments, size and distribution of Synechococcus in the North Atlantic and Pacific Oceans. Limnol Oceanogr 35: 45-58.

Overmann J, Beatty T, Hall KJ, Pfennig N, Northcote TG. (1991). Characterization of a dense, purple sulfur bacterial layer in a meromictic salt lake. Limnol Oceanogr 36: 846-859.

Overmann J, Pfennig N. (1989). Pelodictyon phaeoclathratiforme sp. nov., a new brown colored member of the Chlorobiaceae forming net-like colonies. Arch Microbiol 152: 401-406.

Parkin TB, Brock TD. (1980). The effects of light quality on the growth of phototrophic bacteria in lakes. Arch Microbiol 125: 19-27.

Pegau WS, Gray D, Zaneveld JRV. (1997). Absorption and attenuation of visible and near-infrared light in water: dependence on temperature and salinity. Appl Opt 36: 6035-6046.

Pfennig N. (1967). Photosynthetic bacteria. Annu Rev Microbiol 21: 285-324.
Pick FR. (1991). The abundance and composition of freshwater picocyanobacteria in relation to light penetration. Limnol Oceanogr 36: 1457-1462.

Pierson BK, Sands VM, Frederick JL. (1990). Spectral irradiance and distribution of pigments in a highly layered marine microbial mat. Appl Environ Microbiol 56: $2327-2340$.

Pope RM, Fry ES. (1997). Absorption spectrum (380$700 \mathrm{~nm}$ ) of pure water. II. Integrating cavity measurements. Appl Opt 36: 8710-8723.

Rocap G, Larimer FW, Lamerdin J, Malfatti S, Chain P, Ahlgren NA et al. (2003). Genome divergence in two Prochlorococcus ecotypes reflects oceanic niche differentiation. Nature 424: 1042-1047.

Rueffler C, Van Dooren TJM, Leimar O, Abrams PA. (2006). Disruptive selection and then what? Trends Ecol Evol 21: 238-245.

Sabehi G, Kirkup BC, Rozenberg M, Stambler N, Polz MF, Béjà O. (2007). Adaptation and spectral tuning in divergent marine proteorhodopsins from the eastern Mediterranean and the Sargasso Seas. ISME J 1: 48-55.

Sathyendranath S, Platt T. (1989). Computation of aquatic primary production: extended formalism to include effect of angular and spectral distribution of light. Limnol Oceanogr 34: 188-198.

Schluter D. (2000). Ecological character displacement in adaptive radiation. Am Nat 156: S4-S16.

Segelstein DJ. (1981). The Complex Refractive Index Of Water, PhD thesis, University of Missouri: Kansas City, USA.

Sogandares FM, Fry ES. (1997). Absorption spectrum (340-640 nm) of pure water. I. Photothermal measurements. Appl Opt 33: 8699-8709.

Stomp M, Huisman J, de Jongh F, Veraart AJ, Gerla D, Rijkeboer $\mathrm{M}$ et al. (2004). Adaptive divergence in pigment composition promotes phytoplankton biodiversity. Nature 432: 104-107.

Stomp M, Huisman J, Vörös L, Pick FR, Laamanen M, Haverkamp T et al. (2007). Colourful coexistence of red and green picocyanobacteria in lakes and seas. Ecol Lett 10: 290-298.

Tam AC, Patel CKN. (1979). Optical absorptions of light and heavy water by laser optoacoustic spectroscopy. Appl Opt 18: 3348-3358.

Ting CS, Rocap G, King J, Chisholm SW. (2002). Cyanobacterial photosynthesis in the oceans: the origins and significance of divergent light-harvesting strategies. Trends Microbiol 10: 134-142.

Toledo G, Palenik B, Brahamsha B. (1999). Swimming marine Synechococcus strains with widely different photosynthetic pigment ratios from a monophyletic group. Appl Environ Microbiol 65: 5247-5251.

Vila X, Abella CA. (1994). Effects of light quality on the physiology and the ecology of planktonic green sulfur bacteria in lakes. Photosynth Res 41: 53-65.

Vila X, Abella CA. (2001). Light-harvesting adaptations of planktonic phototrophic micro-organisms to different light quality conditions. Hydrobiologia 452: 15-30.

Vörös L, Callieri C, Balogh KV, Bertoni R. (1998). Freshwater picocyanobacteria along a trophic gradient and light quality range. Hydrobiologia 370: 117-125.

Wood AM, Phinney DA, Yentsch CS. (1998). Water column transparency and the distribution of spectrally distinct forms of phycoerythrin-containing organisms. Mar Ecol Prog Ser 162: 25-31.

Wyman M, Fay P. (1986). Underwater light climate and the growth and pigmentation of planktonic blue-green 
algae (cyanobacteria). II. The influence of light quality. Proc $R$ Soc Lond B Biol Sci 227: 381-393.

Xiong J, Fischer WM, Inoue K, Nakahara M, Bauer CE. (2000). Molecular evidence for the early evolution of photosynthesis. Science 289: 1724-1730.
Zubova SV, Melzer M, Prokhorenko IR. (2005). Effect of environmental factors on the composition of lipopolysaccharides released from the Rhodobacter capsulatus cell wall. Biol Bull 32: 168-173.

Supplementary Information accompanies the paper on The ISME Journal website (http://www.nature.com/ismej) 